Near East University Online Journal of Education (NEUJE)

Received: March 07, 2019 Revised: May 13, 2019 Accepted: June 06, 2019

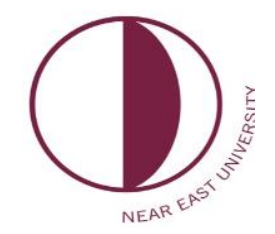

\title{
SUGGESTIONS RELATED TO THE EVALUATION OF THE EXCEL COURSE AT COMPUTER EDUCATION AND INSTRUCTIONAL TECHNOLOGIES DEPARTMENTS
}

\author{
Duygu Mavi ${ }^{1 *}$ \\ ${ }^{1}$ Near East University, duygumavi@gmail.com \\ Correspondence: duygumavi@gmail.com ; Tel.: +0392 2236464
}

\begin{abstract}
The practical application aspect is important for the Excel course included in the curriculum of the Computer Education and Instructional Technologies Department (CEIT). However, the approach adopted when it comes to evaluations and grading is one sided. This study takes the example of an Excel course offered at the Near East University Ataturk Faculty of Education CEIT department and evaluates it according to the Metfessel-Michael program evaluation model. This evaluation was conducted within the timeframe as stated in the schedule. The study used mixed methods research and the opinions of students, employees working in this field, teaching staff and various administrators were collected via questionnaire, observation forms and face to face interviews. Quantitatively the differences between the two classes were evaluated according to common criteria and the correlative technique was used. This study concludes that as the Excel course has a large practical component, a multifaceted evaluation method with practical examinations and in-class assignments at the computer would better evaluate the students' achievements. This study also discovered a need for regulations that would allow the use of the results of practical Excel examinations as exam results.
\end{abstract}

Keywords: computer education and instructional technologies department (CEIT), excel lecture, evaluation, student success

\section{Introduction}

Current technological advances and the need for an information society make it necessary for individuals to be informed and capable in many different aspects. Technology literacy is one of the abilities individuals must hone. Technology is any service or product that facilitates the life of individuals and societies. Thus, if individuals understand technology and it is embraced on a societal level (Bacanak, Karamustafaoglu \& Kose, 2003) it will be easier to answer the needs of a society. Web (2003) puts technology in five main categories: objects, information, activities, methods and socio-technical systems. Curricula for early education in technology is the main factor in the dissemination of technology literacy and this element must be planned accordingly. The "Computer Education and Instructional Technologies Department" is one of the important endeavours to reach this goal. The department offers a four-year program and was opened in the 1989/90academic year by YÖK under the initiative to restructure faculties of education and graduated its first students in the 2001-2002 academic year (Buyukozturk, 2002). The main goal of the program is to train experts who are up-to-date 
on the changes and developments in the field of information and communication technologies, and who are able to offer distance education on these topics (Near East University, 2018). It is in the nature of the department to update itself according to current approaches in societal needs. Evolving is the only way this department can train the kind of people who can answer the needs of its target demographic.

\section{Conceptual Framework}

If a curriculum is not updated regularly and according to developments, changes, individual and societal needs, it will become inadequate with time and will eventually become obsolete. Therefore, curricula should be revised and updated regularly. In order for this to be possible, program evaluations should be made a part of the process and these evaluations should offer feedback on the application of the program. Program evaluation is not a haphazard process and sheds a light on the coordination between all the elements that make up the program. Program evaluation is a systematic and planned process aimed at collecting data on programs that are currently or are going to be in practice. The data collection process is conducted in steps and with a systematic approach and the results offer the opportunity to make decisions on the entirety or one part of the program (Erden, 1998; Fitzpatrick, James \& Blaine, 2004). Fitzpatrick, Sanders and Worthen (2011) state that program evaluation optimizes the object being evaluated (program, course, material, production etc.) and helps the object in achieving its goal. Taylor-Powell, Steele and Douglah (1996) state that the program evaluation process is made up of four steps, namely focusing on evaluation, data collection, using the information and managing the evaluation. They also write that the evaluation aims to look for answers to questions concerning the aim of the evaluation, the information one wants to gain and what will be done with the data collected.

Program evaluation is a process used to make certain decisions concerning a program. According to Cronbach (2000), program evaluation at its core is used to make three types of decision which are developing the course, administrative issues and individual issues. Oliva (2009) states that program evaluation is used for decisions related to curricula and according to Stufflebeam (2003) program evaluation is a guide for making decisions and provides the opportunity to make decisions on understanding the nature of the dynamics of the phenomena being evaluated. It is clear from these explanations that program evaluation is a process which requires the systematic and incremental collection of data with the aim of using it to make decisions related to the object being evaluated.

We see that evaluation is a fundamental aspect of the learning process when we look at the regular and systematic contributions it makes to its quality. Program evaluation produces data on the level to which a program, whether in practice or being planned, is achieving its goals (Tunc, 2010) and provides the opportunity to evaluate a programs strengths and weaknesses before it is disseminated (Ornstein \& Hunkins, 2004).

The Metfessel-Michael evaluation model was developed in the 1960s and is a goal-oriented model. The model emphasizes the production of guiding principles for school programs and aims to actively include school personnel in the program evaluation process. The MetfesselMichael evaluation model is made up of eight steps (Michael \& Metfessel, 1967; Ornstein \& Hunking, 2004; Stufflebeam \& Shinkfield, 1990; Usun, 2012). 


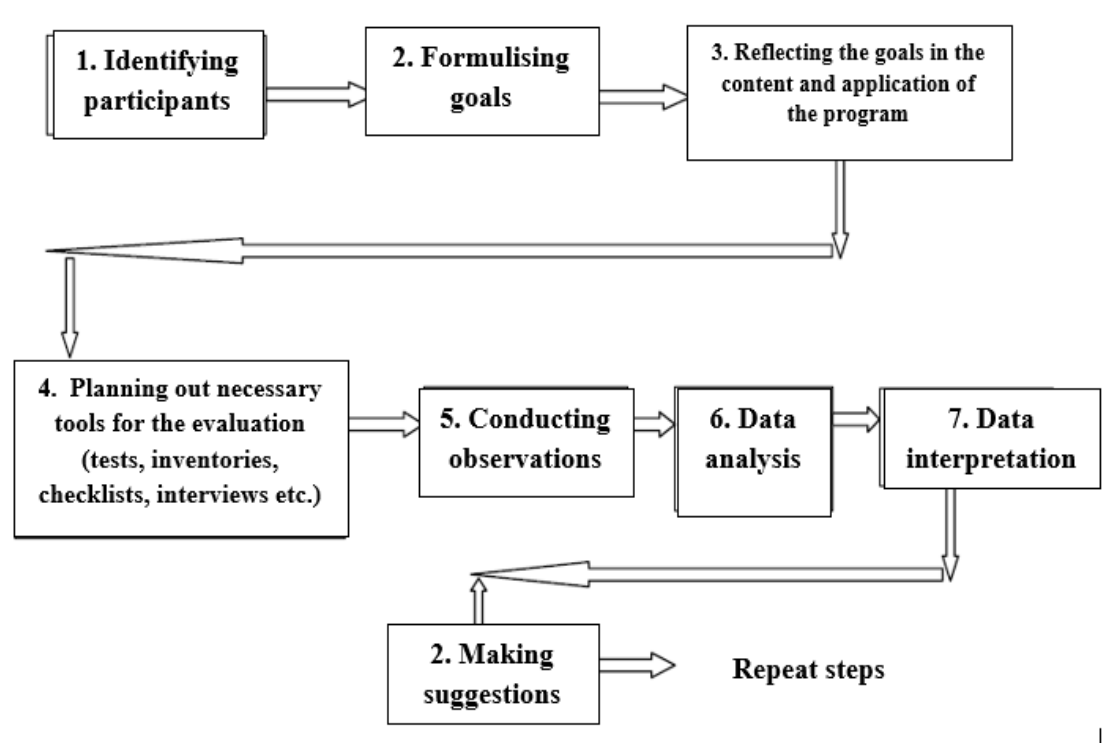

Figure 1. Metfessel-Michael Evaluation model steps

As seen in Figure 1, the Metfessel-Michael evaluation model is an eight-step model and aims to collect regular data on the program being evaluated. To this end the model includes the development of data collection tools and analyzes the data collected in order to fix the content of the program in question (Demirel, 1999; Ozdemir, 2009). The model also includes all efforts in the development of various tools (evaluation) to aid the program in achieving its goals (Popham, 1988). This model is different form other goal-oriented models in that it highlights the use of alternative evaluation tools and comparing the goals of the program with various standards (Yuksek \& Saglam, 2012).

The Metfessel-Michael evaluation model was used for the evaluation of the Excel course because this model offers guidance to experts working on the program being evaluated (Usun, 2012) and because all stakeholders in the program are included, thus focusing on the cohesion between the program goals and outputs.

\section{Methodology}

This study is a program evaluation designed using the mixed methods research approach and both qualitative and quantitative research patterns. The mixed methods research approach is defined as a combination of qualitative and quantitative approaches and concepts (Cresswell, 2003). This approach offers the researcher the opportunity to collect comprehensive data through the use of many methods and approaches (Johnson \& Turner, 2003). Mixed methods research enables the use of qualitative and quantitative approaches together, thus making it more likely that the problem being investigated will be better solved or better understood (Cresswell, 2006). One of the main goals of mixed methods research is to achieve a deeper understanding of a subject, event or phenomenon rather that validate one opinion or situation (Onwuegbuzie \& Leech, 2004). This method was chosen because this study aimed to evaluate the various aspects of a single course. Thanks to this approach, the qualitative and quantitative data collected in relation to the Excel course being evaluated were comprehensive and in-depth. 


\subsection{The Aim of the Study}

The aim of this study is to evaluate the "Excel" course offered at the Near East University department of computer education and instructional technologies using the Metfessel-Michael program evaluation model and make suggestions about the program according to the evaluation conducted.

\subsection{Sample}

The sample of the study includes 10 lecturers from the Near East University Computer Education and Instructional Technologies Department, 280 students studying at this department who had taken the Excel course at the time the study was conducted, 5 research assistants from the department and 40 persons in fields were Excel is used.

\subsection{Data Collection Tools}

Two data collection tools were used in this study, a questionnaire and an interview form.

\subsubsection{Questionnaire}

The questionnaire used in this study was developed by the researcher for students at the computer education and instructional technology department and who have taken part in the Excel course. The aim of the questionnaire is to ascertain the students' opinions on the lecturers delivering the course. The students evaluated the lecturers' teaching methods and performance. The questionnaire is made up of 10 Likert type items graded on a scale of 1-5 (1-very bad, 2bad, 3-average, 4-good and 5-very good). See Appendix 1 for questionnaire.

\subsubsection{Interview Form}

Another data collection tool used in the study is the interview form. This interview form was prepared with computer education and instructional technologies lecturers. The interview contains 10 semi-structured questions. These questions were prepared to elicit evaluations concerning all aspects of the Excel course (i.e. materials, classrooms, content, practical applications, administrative contributions, student engagement and course costs). See Appendix 2 for the interview questions.

\subsection{Planning of the Program Evaluation and Data Collection Process}

The evaluation using the Metfessel-Michael model was conducted in a planned and stepby-step manner. Adhering to the program evaluation model, the data was collected from multiple sources. The program evaluation was conducted between March and May of the 20162017 academic year, spring semester according to the timetable shown in Table 1. 


\begin{tabular}{|l|l|l|l|l|l|l|l|l|l|l|l|l|}
\hline MONTHS & \multicolumn{2}{|l|}{ MART } & \multicolumn{2}{l|}{ NISAN } & \multicolumn{3}{l|}{ MAYIS } \\
\hline WEEKS & 1 & 2 & 3 & 4 & 1 & 2 & 3 & 4 & 1 & 2 & 3 & 4 \\
\hline PROCESSES & & & & & & & & & & & & \\
\hline 1. PLANNING & & & & & & & & & & & & \\
\hline 2. ANALYZING NEEDS & & & & & & & & & & & & \\
\hline 3. IDENTIFYING GOALS & & & & & & & & & & & & \\
\hline 4. IDENTIFYING ACTIONS & & & & & & & & & & & & \\
\hline 5. CONTENT ANALYSIS & & & & & & & & & & & & \\
\hline 6. TABLE OF INDICATORS & & & & & & & & & & & & \\
\hline 7. EDUCATION STATUS & & & & & & & & & & & & \\
\hline $\begin{array}{l}\text { 8. LEVEL ASSESSMENT } \\
\text { EXAM }\end{array}$ & & & & & & & & & & & & \\
\hline 9. OBSERVATION TESTS & & & & & & & & & & & & \\
\hline 10. GUIDEBOOK & & & & & & & & & & & & \\
\hline 11. REPORTING & & & & & & & & & & & & \\
\hline
\end{tabular}

Figure 2. Steps followed during program evaluation

The first step taken in the program evaluation process was planning of the tasks to be fulfilled and the production of the timetable seen above. This stage was also when primary stakeholders (those directly affecting and being affected by the program) were also identified and how they were to be included in the study was also planned. Later on, the students included in the study were given a 10-item questionnaire and face-to-face interviews were conducted with lecturers and administrators at the computer education and instructional technology department in order to ascertain the need for this field in society.

After a comprehensive need analysis, the process moved on to identifying goals and putting the actions we would take into writing. The content was separated into the current status (Excel course content) and goal status (goals and actions/standards). The current and goal status lists were compared and the results were used to develop suggestions on how to change the course content. These status lists were compared using content tests and in-class observation. In this context in order to identify the correct evaluation tools and to conduct the evaluation, in-class practical activities were observed and some content tests were conducted. In the next stage, all qualitative and quantitative data was analyzed and interpreted as per the suitable data analysis techniques chosen. Finally, the program aims were compared to the findings of the study and suggestions were made concerning the future applications of the program in general.

\subsection{Data Analysis Process}

The study obtained both quantitative and qualitative data. First, the data procured from interviews were put into writing and this data was analyzed using qualitative content data analysis techniques. Regarding the data from the questionnaire, the first step was to compile a data template and the data entered into this template was transferred into an SPSS statistics 
program. Descriptive statistics techniques ( $\mathrm{M}, \mathrm{f}$ and \%) were used in the analysis of this data and the student responses were described.

\section{Findings and Comments}

The data obtained from this study can be divided into four groups. These groups are student opinions and suggestions on the Excel course, lecturer opinions and suggestions on the Excel course, administrator opinions and suggestions on the Excel course and societal group opinions and suggestions on the Excel course.

\subsection{Lecturer Opinions and Suggestions on the Excel Course}

The data obtained from lecturers has been shown separated into positive and negative responses in Figure 3.

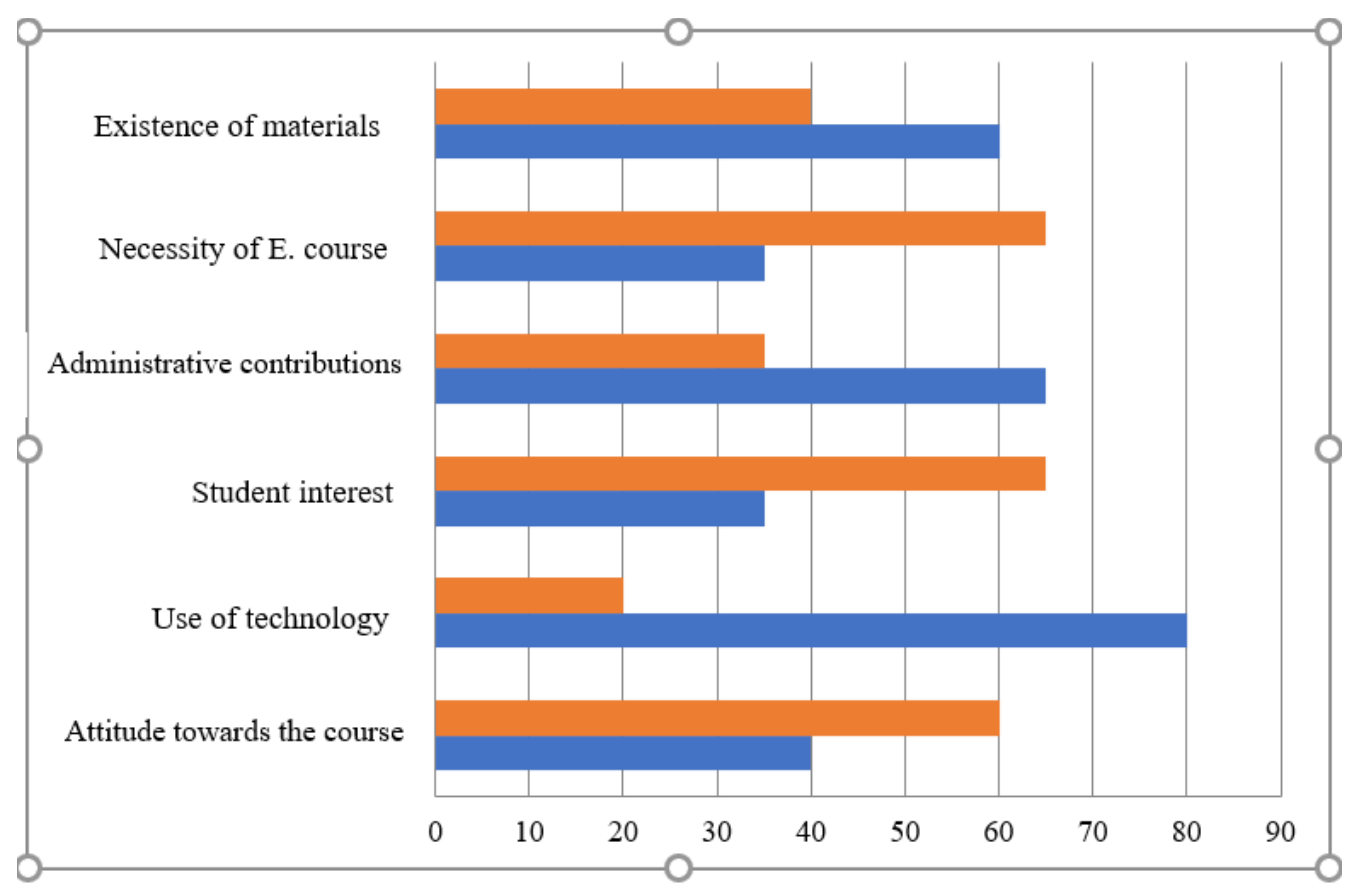

Figure 3. Percentage values of lecturer opinions on the Excel course

The results of the evaluation show that the attitude towards the class is $40 \%$ positive. $80 \%$ of lecturers stated that their teaching materials were used in the classroom but some lecturers and research assistants said this was not the case. 35\% of lecturers said the students were involved with the course. The lecturers' reasons for this lack of interest on the part of the students was that the students do not see university as a place where they learn and develop their skills in the department they are studying at but as a place they just came to get a diploma. $65 \%$ of lecturers report that administration contributes to the financing of classroom materials. $35 \%$ of lecturers believe that the Excel course should be included in the general computer course and the rest were of the opinion that the Excel course should remain separate. The reason they wanted it to stay separate was that offering the content of the Excel course as part of the general computer course would not allow enough time to teach the formulas and applications offered by the program. The proponents of keeping the Excel course separate also stated that allowing more time for in-depth coverage would allow for a deeper understanding of the 
program and/ offer the opportunity to elaborate on the formulas. $60 \%$ if lecturers thought the materials were adequate.

\subsection{Lecturer Opinions and Suggestions on the Excel Course}

The positive and negative opinions obtained from students are shown below in Figure 4.

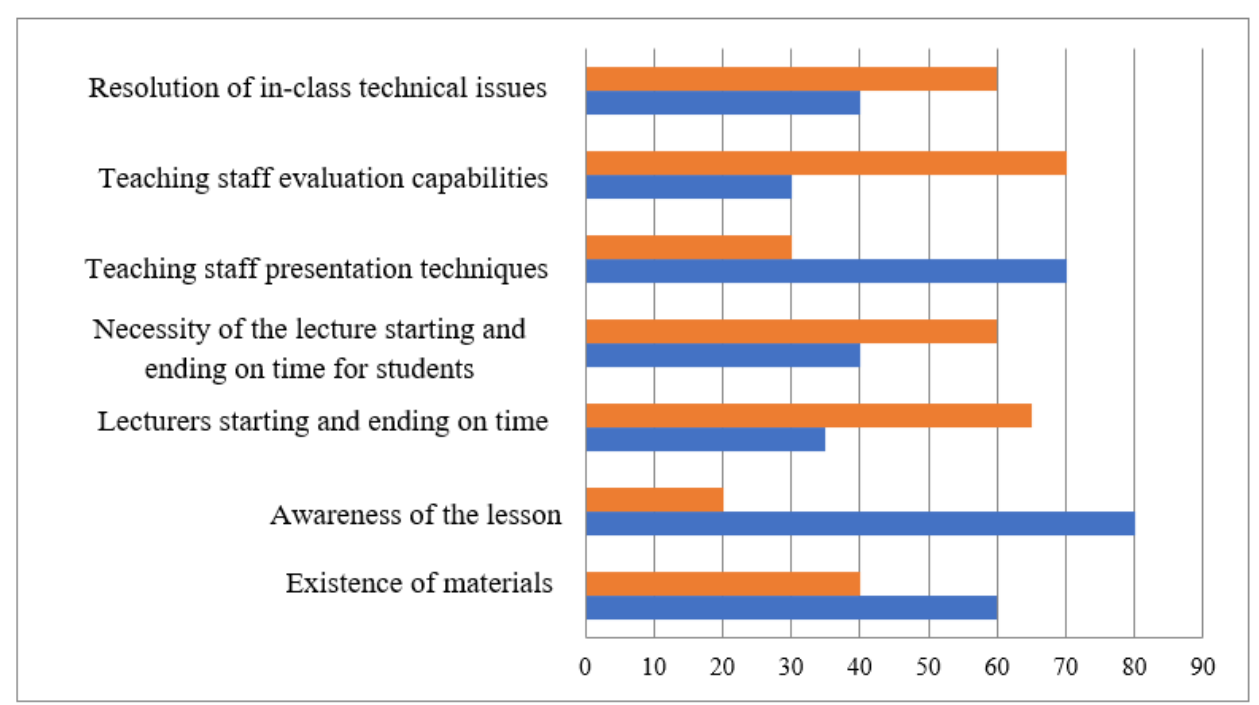

Figure 4. Percentage values related to student opinions on the Excel course

$60 \%$ of students stated that there were materials in the classroom but that some lecturers and assistants did not use them all the time. $80 \%$ of students said they were aware of the reasons why they were taking the class and that the teachers provided feedback but they also reported a need for additional lessons. $35 \%$ of students stated that teachers did not start and finish the lessons on time. When asked in interviews, the students said the reason for this was that there were fixed times given by the university but the teachers were laxer about this issue and focused more on the lesson than the prescribed timetable. $60 \%$ of students also stated that this was not an issue for them. $70 \%$ of students said the teaching methods adopted by the lecturers were successful and appropriate for a university course. They also reported that the positive effects of the course could be felt in seminars and examinations. 30\% of students believed the grading and evaluation of the course was not adequate and fair. The reason stated is that some lecturers engaged in nepotism or favoritism. Students reported that $40 \%$ of technical issues were resolved by assistants and also stated that time was wasted in the event that an assistant was not present in class.

\subsection{Administrator Opinions on the Excel Course}

The positive and negative feedback obtained from administrators is shown in Figure 5. 


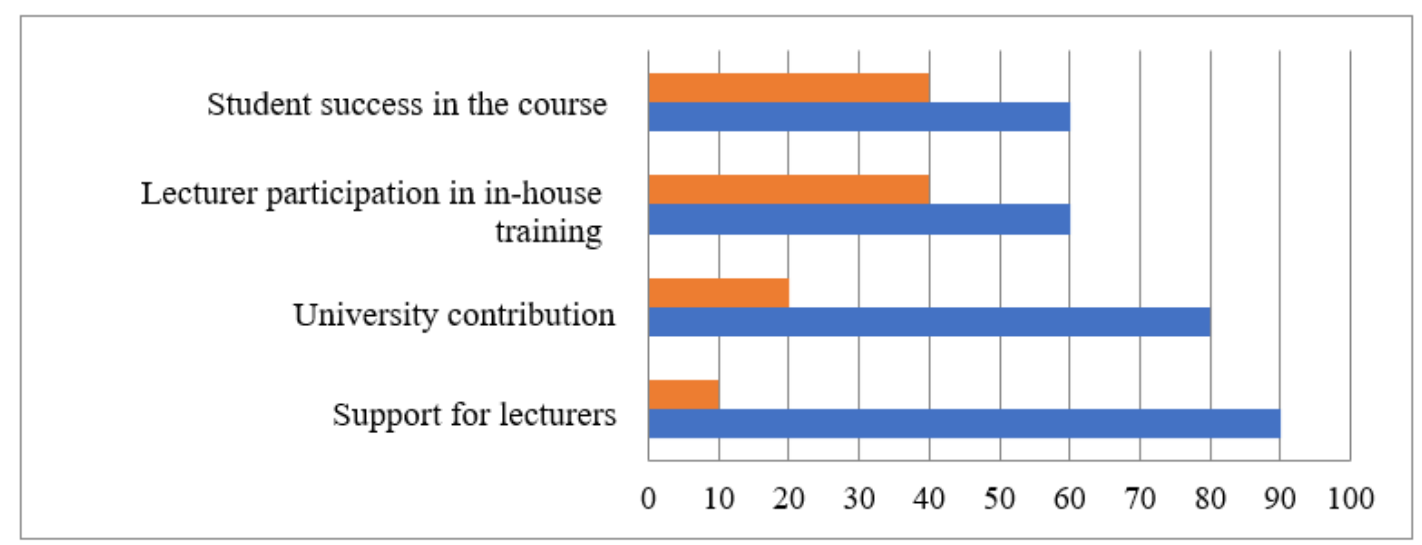

Figure 5. Percentage values related to administrator opinions on the Excel course

Administrators reported $90 \%$ support for lecturers in regard to the Excel course. $80 \%$ of administrators stated the financial contributions by the University was complete and sufficient and that the lecturers were also trained on this course. However, only $60 \%$ of relevant lecturers had attended this training and was interpreted as a lack of willingness to develop their knowledge on the teacher's part. Also, administrators stated that only $60 \%$ of students succeeded in this course and that the failure reflected negatively on the students' opinions of university. The reason given for this situation is that the students don't care about lessons and that students who are from Turkey miss their families and their friends from Turkey.

\subsection{Societal Groups' Opinions and Suggestions on the Excel Course}

The positive and negative feedback received from societal groups that took part in the study is shown below in Figure 6.

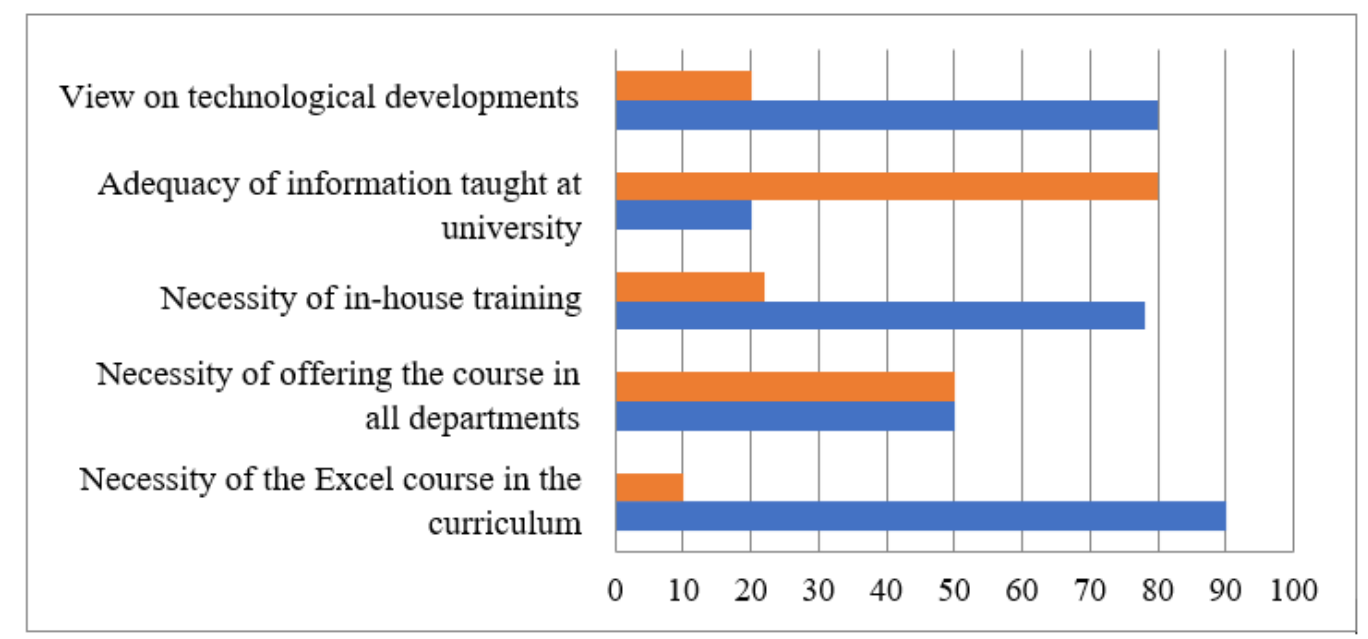

Figure 6. Percentage values related to societal group opinions on the Excel course

90\% of people using Excel in the workplace stated that this course was a necessary component of the University program. The reason given for this opinion is that Excel is a program used often in various fields/sectors. In interviews conducted with people from 
different parts of society who use Excel showed that \%50 of these people believe that this course should be included in the curricula of all departments as the skills and information conveyed in the course are important not only for the job market but also other fields. Also, $78 \%$ of these interviewees argued that workplaces should offer in-house training on this subject and that ministries should also support this initiative. $80 \%$ of interviewees from societal groups said that University students had a lack of knowledge in their field compared to those working in the field and they stated that the reason for this was that they lacked practice, only went to university to get a degree, had family and environmental issues at a young age, were not as financially motivated as those working in the field to learn the subject, and that the students only used the skills they had learnt in class to pass the exam.

\section{Discussion}

The main goal of CEIT departments is to develop the methods and techniques necessary for the effective use of instructional technologies and training computer education teachers who are capable of using these technologies (Erden, 2014). The department also aims to design and develop teaching materials and educational software that are compatible with the level of the children/students from a pedagogical standpoint and also in line with curricula while also training teaching experts who can apply and evaluate these materials (Seferoglu, 2007). Graduates of the CEIT department are not only employed as teachers but also work in various fields concerning information technologies in the private sector according to their knowledge, skills and capabilities. A study of CEIT students showed that they planned to work in various fields and that they were enhancing their abilities accordingly (Karatas, 2010; Kurtoglu \& Seferoglu, 2012). It has been observed that CEIT graduates are employed as teachers, education technologists, training program advisors, advisors, academics (Atun, 2009), and in the information sector and as distance education technicians (Seferoglu, 2007). Taking into account the array of fields CEIT graduates work in, teaching students in accordance with the various demands of the market will aid graduates in taking advantage of employment opportunities. Thus, the opinions of stakeholders from a variety of fields on the capabilities of CEIT graduates and the content of the program are of significant importance. Research shows that teachers who are CEIT graduates believe they are lacking in knowledge regarding the computer, technical information and skills. They have also stated that the CEIT graduate program does not teach students enough on technical issues which causes students to be taught inadequately, and that the CEIT program needs to be updated (Berkant \& Tuncer, 2011; Kiyici $\&$ Kabakci, 2006). These findings highlight the need for and importance of evaluating the CEIT program as a whole or parts of the CEIT program or some courses included in the program.

All programs, lessons, courses or materials aim to be efficient, effective, productive and useful to their target groups. However, sometimes programs become ineffective in terms of fulfilling the demands of student needs, field of study, societal needs or current stakeholders. Thus, the best way to see if a program is adequate and efficient, and whether it is reaching its goals is to evaluate. This evaluation is called program evaluation and is a critical component in highlighting the strengths and weaknesses of a program in order to make decisions on said program (Ornstein \& Hunkins, 2004).

Program evaluation is necessary to program development and is a scientific, step-by-step process that aids in making effective decisions concerning the program. Considering the contributions this evaluation makes to the process and the quality of training activities, it is indispensable to program development. The evaluation process is not a haphazard process and includes consecutive, planned and systematic steps such as data collection, analysis and 
evaluation (Erden, 1998; Fitzpatrick, James \& Blaine, 2004). Stufflebeam (2003) states that program evaluation is a guide for the person authorized to make decisions for a program and is a way to better understand the concept being evaluated. Programs evaluated in accordance with this method end up with decisions such as continuing, revising, changing or cancelling the program (Gozutok, 1999). Therefore, the collection of multifaceted and in-depth data illustrating the efficacy, efficiency, accomplishment of goals along with the processing, analysis and finally evaluation of the program is a vital step that must be taken before any radical decisions are made.

One of the courses taught in-depth at the CEIT program is the Microsoft Office courses. These are computer programs that are commonly used in many different fields. This study evaluates the level to which one of these Microsoft Office courses, namely the level to which the Excel course is achieving its goals, how it is viewed by various stakeholders and has resulted in certain decisions concerning the level to which the Excel course is fulfilling its goals. The program evaluation method chosen is a goal-oriented method and the aim was to ascertain whether the program was reaching its goals, why the goals not being fulfilled weren't being fulfilled and how these situations could be rectified. The Metfessel-Michael evaluation model was chosen because the model values stakeholder contributions when it comes to making decisions on a program (Stufflebeam \& Shinkfield, 1990). The study used all eight steps and goal fulfilment was evaluated by students, lecturers, administrators and other stakeholders.

The fact that the general attitude of lecturers regarding the course was $40 \%$ shows that they think there are some negative sides to the course. Looking at lecturer attitudes to other topics show that there are some areas they see in a negative light. The possible reasons for this negative attitude are insufficient use of technology, student interest in engaging in the class, insufficient support for the course from administrators, administrators' opinions concerning the necessity of the class and the existence of class materials. The students' lack of engagement and lecturers' opinions that the course is unnecessary have the most impact on lecturers' attitudes concerning the course. The lecturers' attitudes are an important factor that can directly affect their performance and may prevent the course from reaching its goals. Thus, it is vital for the success of the course that the underlying reasons for the lecturers' negative attitude is researched in detail.

Showing the attitudes of students regarding the program they are enrolled in will provide guidance on how they can be integrated. Ascertaining student opinions on the program will facilitate their cohesion with the program and its goals (Erdogan, 2008). This study found that student opinions, like lecturer opinions, were that there were insufficient materials but unlike lecturers, students stated that they were highly interested in the classes. Students also said that lecturers did not start and end the classes on time, but they also said that they did not mind this situation. Lecturers may not be adhering to the set schedules because the students do not mind having somewhat irregular class hours. On the other hand, most students responded positively on questions concerning the lecturers' teaching methods but also said they were lacking in evaluation capabilities and in resolving technical issues arising in class. When we look at it from the students' point of view, this course needs revision on class hours, evaluations and the resolution of technical issues. In line with the findings of this study, Atun and Ates (2008) stated in their study of CEIT students that the main issue students had were educational issues, the lack of technical courses offered and the surplus of courses on subjects in other fields. Another study conducted by Dursun and Kuzu (2008) also reported findings similar to those contained in this study. 
This study also looked into high level administrators' opinions on the planning, integration and evaluation of the course and even though there were some negative opinions on the students and the lecturers, the administrators held positive views on support for lecturers, university contribution to the course, lecturers' participation in training and the achievements of the students taking the course. These findings show that the administration says they are offering all support (lecturers, infrastructure, training, etc.) necessary for the success of the course and this means the students are also succeeding. However, these findings are incompatible with student and lecturer opinions on the adequacy of the materials and the technical issues in class. The administration argues that they are providing adequate support for the program but the students and lecturers do not agree with this statement, highlighting a lack of communication between upper administration and those directly involved in the lessons and that the issues with the course are not being relayed to the administrators.

Teaching is not the only area of employment open to CEIT graduates and students plan to enter and later take part in a diverse range of sectors, even while still at school (Erdogan, 2008; Atun, 2009). Tugs, the opinions and demands of stakeholders from different sectors on the graduates of this department must be included in differences made in regards to program evaluation. This study shows that the opinions of societal group on the topic of this course are that they find the Excel course to be of importance and they believe there should be in-house training on this topic because they care about technological developments, on the other hand they were unsure about the necessity of offering this class for all departments and stated that the information produced at universities was inadequate.

Even though upper administration states that the planning and support necessary for this course to succeed is provided, lecturers and students report a lack of materials and technical support. Lecturers also made note of a lack of interest on the part of the students and students highlighted poor time management and inadequate evaluations on the part of the lecturers. The sum of these findings, also taking into account the opinions of societal groups proves that the Excel course included in the CEIT program needs to be revised with all stakeholders' contributions.

\section{Conclusion and Suggestions}

This study is a systematic and step-by-step program evaluation of the Near East University Atatürk Faculty of Education CEIT Department based on the Metfessel-Michael program evaluation model. The study was conducted using mixed methods research and included a wide sample group made up of students who have taken the course, lecturers, administrators who plan the course and other stakeholders in society. The study has reached certain conclusions in light of the findings.

\section{Lecturers:}

Lecturers were found to have a negative attitude towards the course and it was concluded that most of them used the educational materials in class. Findings also showed that the lecturers' opinion of student interest was low, more than half of them believe administrators are in support of the courses, a large part of them believe the Excel course is unnecessary and more than half of them think the materials offered are adequate. 


\section{Students:}

A little more than half of the students see the materials provided as adequate, the majority are aware of why they are taking the course, a third believe lecturers start and end the classes on time, almost half believe adhering to set class hours is important, more than two thirds believe teachers are not effective and fair in their grading of the class and half believe most technical issues that arise in class are resolved by assistants.

\section{Administrators:}

The conclusions drawn from administrators are that there is strong support for lecturers on the topic of this course, the amount of financial support for the course is very high, about half the lecturers are unwilling to participate in training and about half of the students are successful in this course.

\section{Other stakeholders:}

A large majority of stakeholders from different facets of society believe this course should be a part of university programs, half believe this course should be offered in all programs, about four fifths report a need for in-house training on the content of this course, four fifths believe the information conveyed in Excel courses are insufficient and these stakeholders view technological developments in a positive light.

Based on data collected from students, lecturers, administrators and different facets of society, the following solutions were made to the Near East University, Computer Education and Instructional Technologies Department in connection with the Excel course offered at this department.

- In-house training should be provided for not only current lecturers but also assistants and new lecturers. Part-time employees should also have in-depth knowledge on this subject. Thus, giving them the opportunity to keep up with new and developing technology and enhance their abilities.

- Lecturers should start and end classes according to the schedule in order to make the course more effective and are advised to use various tools, methods and evaluation techniques.

- The psychological state and various negative situations (i.e. missing their families) have a negative impact on their success and participation in the course. These students should receive one-on-one attention, be offered guidance counselling services and be reintegrated into the classroom. Lecturers should also inform students about the course and how it will contribute to their future in order to motivate students.

- Administrators should meet with lecturers and experts to review the course and make the content clearer, more enjoyable and up to date.

- Assistants should know where they stand when in comes to participating in the class. They should be offered in-house training on this issue and they should be more careful when it comes to their dialogue with the students.

- Lecturers should grade assignments and papers anonymously as to prevent the students from thinking they are favoring certain students and the students will be more motivated for the lessons.

- The course should be restructured providing needs are ascertained according to the state and people working in society.

- There should be internship opportunities for students so they can develop and ingrain the knowledge and skills they gain during the Excel course and so they can see various applications of the knowledge in the field. 
- The physical environment in the computer laboratories and the layout of the computers have an important affect on learning-teaching processes and the learning environments should be reorganized according to the needs stated about this issue.

- Expert opinions should be solicited when the computer lab is being set up.

- The resources of the computer laboratories (personnel, experts, environment, tools, equipment, etc.) should be enriched.

Lecturers are of the opinion that as the Excel course is based on practical applications, practical examinations and in-class assignments are better ways of evaluating students. With this in mind, there should be some regulations made on the issue of using the results of practical examinations as exam results.

\section{References}

Bacanak, A., Karamustafaoğlu, O., \& Kose, S. (2003). Yeni bir bakis: Egitimde teknoloji okuryazarligi. Pamukkale Universitesi, Egitim Fakultesi Dergisi, 2(14), 191-196.

Buyukozturk, S. (2002). Bilgisayar ve ogretim teknolojileri ogretmenligi ile sinif ogretmenligi programi ogrencilerinin akademik basarilarini etkileyen faktorler. Egitim Yonetimi, 8(30), 187-204.

Creswell, J. W. (2003). Research design: Qualitative, quantitative, and mixed methods approaches (2nd ed.). Thousand Oaks, CA: Sage.

Creswell, J. W. (2006). Understanding mixed methods research, (Chapter 1). Available at: http://www.sagepub.com/upm-data/10981_Chapter_1.pdf

Cronbach, L. J. (2000). Course improvement through evaluation, Evaluation in Education and Human Services, 49, 235-247.

Demirel, O. (1999). Egitimde program gelistirme. Ankara: Pegem Publishing.

Taylor-Powell, E., Steele, S., \& Douglah, M. (1996). Planning a programme evaluation. University of Wisconsin. Retrieved on 09.12 .2017 on http://learningstore.uwex.edu/assets/pdf/g3658-pdf

Erden, M. (1998). Egitimde program degerlendirme. Ankara: Ani Publishing.

Fitzpatrick, J., James, S., \& Blaine W. (2004). Program evaluation: Alternative approaches and practical guidelines. Boston: Pearson Publishing.

Fitzpatrick, J. L., Sanders, J. R., \& Worthen, B. R. (2011). Program evaluation alternative approach and practical guidelines. Boston: Pearson Publishing.

Oliva, P. F. (2009) Developing the Curriculum, New York: Pearson Allyn and Bacon.

Onwuegbuzie, A.J., \& Johnson, R.B. (2004). Mixed method and mixed model research. In Johnson, R.B., Christensen, L.B. (Eds.) Educational Research: Quantitative, Qualitative, and Mixed Approaches, (pp. 408 - 431). Allyn and Bacon, Needham Heights, MA.

Ornstein, Allan C., \& Hunkins Francis P. (2004). Curriculum: Foundations, principles and issues. Englawood Cliffs, NJ, Prentice Hall. 
Ozdemir, S. (2009). Egitimde program degerlendirme ve Turkiye'de egitim programlarini degerlendirme çalismalarinin incelenmesi. Yuzuncu Yil Universitesi Egitim Fakultesi Dergisi, 6(2), 126-149.

Popham, W. J. (1988). Educational evaluation. Englewood Cliffs, New Jersey: Prentice Hall.

Stufflebeam, D. L. (2003). The CIPP model of evaluation. In T.Kellaghan, D.L. Stufflebeam and L.A. Wingate, International handbook of educational evaluation (pp. 31-62). Boston: Kluwer Academic Press.

Stufflebeam, D. L., \& Shinkfield, A. J. (1990). Systematic evaluation. Boston: Kluwer - Nijhoff Publishing.

Tunc, F. (2010). Evaluation of an English language teaching program at a public university using CIPP model (Unpublished master thesis). Orta Dogu Teknik Universitesi, Institute of Social Sciences, Ankara.

Yuksel, I., \& Saglam, M. (2012). Egitimde program degerlendirme. Ankara: Pegem Publishing.

Usun, S. (2012). Egitimde program degerlendirme - Surecler, yaklasimlar ve modeller. Ankara: Ani Publishing.

Web, (2003). Technological questions and issues; what is technology? Retrieved from http://atschool.eduweb.co.uk/trinity/watistec.html

\section{Biodata of the Corresponding Author}

Duygu Mavi was born in Istanbul in 1988. She graduated from the Near East University Department of Computer Education and Instructional Technologies (CEIT) and started work at the same university as an assistant. She later completed her master's degree at the Department of Curriculum and Instruction (CI) and is currently in the process of writing her doctoral thesis at the same department. Duygu Mavi is also a maker teacher and is involved in STEM research. 